\title{
MICROHABITAT USE BY TWO ROCKY SHORE GASTROPODS IN AN INTERTIDAL SANDY SUBSTRATE WITH ROCKY FRAGMENTS
}

\author{
TURRA, A..$^{1,2,3}$ and DENADAI, M. R. ${ }^{1,2}$ \\ ${ }^{1}$ Departamento de Zoologia, Instituto de Biologia, Unicamp, Campinas, SP, Brazil \\ ${ }^{2}$ Instituto Costa Brasilis, Desenvolvimento Sócio-Ambiental, C. P. 32, Ubatuba, Brazil \\ ${ }_{3}^{3}$ Departamento de Oceanografia Biológica, Instituto Oceanográfico, Universidade de São Paulo, São Paulo, SP, Brazil \\ Correspondence to: Alexander Turra, Departamento de Oceanografia Biológica, Instituto Oceanográfico, \\ Universidade de São Paulo, São Paulo, SP, Brazil, e-mail: alexander.turra@gmail.com \\ Received July 13, 2004 - Accepted August 18, 2004 - Distributed February 28, 2006
}

(With 1 figure)

\begin{abstract}
Sandy beaches in some areas of the São Sebastião Channel in southeastern Brazil have unremittingly undergone a variety of impacts, including the deposition of rock fragments in the intertidal region. Consequently, these environments support a rich fauna comprising both sandy beach and rocky shore organisms. Two rocky shore gastropods, Tegula viridula and Morula nodulosa, are particularly abundant in such environments. An evaluation of the use of microhabitats by these two species revealed that they occupy the available microhabitats in different proportions and the presence of one species is associated with the absence of the other. Morula nodulosa is randomly dispersed, occupying mostly areas with rock fragments covered with sediment and branching brown algae. Tegula viridula shows a clumped dispersion associated with the patchiness of the microhabitats used: the presence of encrusting green algae and absence of sediment and branching brown algae covering the rocks. These findings suggest $T$. viridula has a lower tolerance than $M$. nodulosa to sand inundation of the rocky fragments, a stochastic event common to the environment in question.
\end{abstract}

Keywords: Tegula viridula, Morula nodulosa, spatial heterogeneity, clustered dispersion.

\section{RESUMO}

\section{Uso de microhabitats por dois gastropodes de costão rochoso em um substrato arenoso entremarés com fragmentos rochosos}

Praias arenosas em algumas partes do Canal São Sebastião, região sudeste do Brasil, têm sido constantemente submetidas a diferentes tipos de impacto como deposição de fragmentos rochosos na região entremarés. Como consequiência, estes ambientes abrigam uma rica fauna com organismos tanto de costões rochosos quanto de praias arenosas. Em especial, duas espécies de gastrópode típicas de costões rochosos, Tegula viridula e Morula nodulosa, são muito abundantes nestes ambientes. Uma avaliação do uso de microhabitats por estas duas espécies revelou que elas ocupam os microhabitats disponíveis em diferentes proporções e que a presença de uma espécie esteve associada à ausência da outra. Morula nodulosa apresentou uma dispersão ao acaso ocupando áreas com sedimento e algas marrons ramificadas recobrindo os fragmentos de rocha. Tegula viridula apresentou uma dispersão agrupada associada à característica agrupada dos microambientes ocupados: presença de algas verdes incrustantes e ausência de sedimento e algas marrons ramificadas recobrindo os fragmentos de rocha. Os resultados indicam que $T$. viridula pode ser menos tolerante que $M$. nodulosa à inundação dos fragmentos rochosos por sedimento, um evento estocástico comum ao ambiente estudado.

Palavras-chave: Tegula viridula, Morula nodulosa, heterogeneidade espacial, dispersão agrupada. 


\section{INTRODUCTION}

Tegula viridula (Gmelin, 1791) is an intertidal trochid gastropod that feeds on encrusted algae (Moreira-Filho, 1960), while Morula nodulosa (C. B. Adams, 1845) is a small drilling muricid predator (Magalhães, 2000). The shells of these gastropods are frequently used by sympatric hermit crab species (Leite et al., 1998) and are also collected by local handicraftsmen for the production of souvenirs. These gastropods are commonly found in the intertidal and shallow sub-tidal regions along the rocky shores of the São Sebastião Channel in southeastern Brazil (Migotto et al., 1993; Denadai \& Amaral, 1999; Magalhães, 2000) and may be important agents in structuring intertidal communities (Magalhães, 2000).

The São Sebastião Channel is located between the mainland and São Sebastião Island and its coastal region has undergone intense urbanization over the last fifty years, as evidenced by the many resorts, homes and roads along the coastline. Because the coast is extremely embayed by nearby crystalline formations, explosions to create new areas for roads and buildings used to be very frequent. The rock fragments resulting from these activities were dumped on several sandy beaches, where the action of waves spread them along the sandy strands (see Denadai \& Amaral (1999) for a detailed description of such environments). This resulted in a particular environment composed of sand and rock fragments (pebbles, cobbles and some isolated boulders) that are colonized by organisms from both sandy beaches and rocky shores (Amaral et al., 2003). The Engenho d'Água beach is an example of this kind of environment in the São Sebastião Channel. This environment seems to be more stable than typical sandy beaches and more dynamic than typical rocky shores. In fact, changes in this habitat occur by rock dislodgement and coverage by sand during sea storms (Denadai et al., 2000). The high habitat complexity caused by the rock fragments creates space for the settlement of fouling organisms and the rocks are also used as refuges by the mobile fauna during low tides. This also enhances food availability to both herbivorous (T. viridula) and carnivorous ( $M$. nodulosa) organisms. This paper purports to describe the patterns of dispersion and microhabitat use by two abundant rocky shore gastropods (Tegula viridula and Morula nodulosa) in the intertidal region of an anthropogenically created sandy substrate with rock fragments.

\section{MATERIAL AND METHODS}

The two gastropods studied here were collected in the intertidal region of the Engenho d'Água beach of São Sebastião Island on the northern coast of the state of São Paulo, Brazil. A rectangular area of $50 \times 4 \mathrm{~m}$ parallel to the water line and near the infralittoral fringe was selected, given the high abundance of both $T$. viridula and M. nodulosa. From June 98 to May 99, thirty random samples were collected monthly from $0.50 \times 0.50 \mathrm{~m}$ quadrats.

The most conspicuous characteristics of the substrate recorded for each quadrat were the presence of sediment covering the rocks, branching brown algae, and encrusting green algae. The monthly samples were pooled for the present analysis. The dispersion pattern of these two populations was evaluated according to Elliott (1977), by calculating a dispersion index (I) and the parameter of its associated statistical distribution (d). The significance of these values was verified by comparing them with critical $d$ values $\left(d_{0.05}=1.96 ; d_{0.001}=3.29\right)$. Thus, $d<d_{\text {critical }}$ (positive or negative sign) indicates random dispersion $\left(S^{2}=\bar{x}\right.$, where $S^{2}$ is the variance and $\bar{x}$ the mean); $\mathrm{d}>\mathrm{d}_{\text {critical }}$ (negative sign) indicates regular dispersion $\left(\mathrm{S}^{2}<\overline{\mathrm{X}}\right) ; d>d_{\text {critical }}$ (positive sign) indicates clumped dispersion $\left(S^{2}>\bar{x}\right)$.

\section{RESULTS}

The two populations showed different dispersion patterns, with $T$. viridula presenting a highly significant clumped dispersion $(\mathrm{I}=3529.951, \quad \mathrm{~d}=49.987$, df $=299)$ while M. nodulosa was randomly dispersed throughout the study area $(\mathrm{I}=520.583, \mathrm{~d}=1.617, \mathrm{df}=299)$. A comparison of the microhabitat use of the two species (Table 1, "between species") revealed that they occupy the microhabitats in different proportions. In fact, M. nodulosa was recorded more frequently in substrates with sediment and branching brown algae covering the rocks, while T. viridula showed a clear association with areas with encrusting green algae (Table 1). In addition, T. viridula used proportionally the microhabitats 
without sediment and brown algae and with green algae, as indicated by the significant differences in the proportion of used $v s$. available substrate types. $M$. nodulosa showed the opposite behavior, using the three microhabitats in the same proportion as their availability in the area. The dissimilar use of microhabitats by these two species is more evident when one analyzes the abundance relationship of the samples (Fig. 1). In other words, the presence of one species in high abundance was found to be

TABLE 1

Comparison of the number of samples containing Tegula viridula and Morula nodulosa with regard to the presence and absence of sediment, branching brown algae, and encrusting green algae in the rock fragments (see $\chi^{2}$ between species). Comparison of the number of samples containing Tegula viridula and Morula nodulosa and the number of all samples (available) in terms of the presence and absence of sediment, branching brown algae, and encrusting green algae in the rock fragments (see $\chi^{2}$ use $v s$. availability) ( $\mathrm{n}=\mathbf{2 4 0}$ samples; $\chi^{2}$, Chi-square statistic; df, degrees of freedom; and p, associated probability).

\begin{tabular}{|c|c|c|c|c|c|}
\hline \multirow{2}{*}{$\begin{array}{c}\text { Environmental } \\
\text { parameter/Gastropod }\end{array}$} & \multicolumn{2}{|c|}{ Used } & \multicolumn{2}{|c|}{ Available } & \multirow{2}{*}{$\begin{array}{c}\chi^{2} \\
\text { (Use } v \text { s. Availability }\end{array}$} \\
\hline & Presence & Absence & Presence & Absence & \\
\hline \multicolumn{6}{|l|}{ Sediment } \\
\hline T. viridula & 54 & 95 & \multirow[t]{2}{*}{149} & \multirow[t]{2}{*}{91} & $23.106 * * *$ \\
\hline \multirow[t]{2}{*}{ M. nodulosa } & 116 & 33 & & & $0.457^{\mathrm{ns}}$ \\
\hline & \multicolumn{2}{|c|}{$\chi_{\text {between species }}^{2}=15.080 * * *$} & & & \\
\hline \multicolumn{6}{|l|}{ Branching brown algae } \\
\hline T. viridula & 50 & 80 & \multirow[t]{2}{*}{148} & \multirow[t]{2}{*}{92} & $29.393 * * *$ \\
\hline \multirow[t]{2}{*}{ M. nodulosa } & 117 & 63 & & & $0.885^{\text {ns }}$ \\
\hline & \multicolumn{2}{|c|}{$\chi_{\text {between species }}^{2}=20.339 * * *$} & & & \\
\hline \multicolumn{6}{|l|}{ Encrusting green algae } \\
\hline T. viridula & 44 & 86 & \multirow[t]{2}{*}{60} & \multirow[t]{2}{*}{180} & $5.209 *$ \\
\hline \multirow[t]{2}{*}{ M. nodulosa } & 39 & 141 & & & $1.183^{\mathrm{ns}}$ \\
\hline & \multicolumn{2}{|c|}{$\chi_{\text {between species }}^{2}=5.107^{*}$} & & & \\
\hline
\end{tabular}

$\mathrm{df}=1$ for all comparisons (Yates' correction employed). ${ }^{*} \mathrm{p}<0.05 ; * * * \mathrm{p}<0.001 ;$ and ${ }^{\mathrm{ns}}$ not significant.

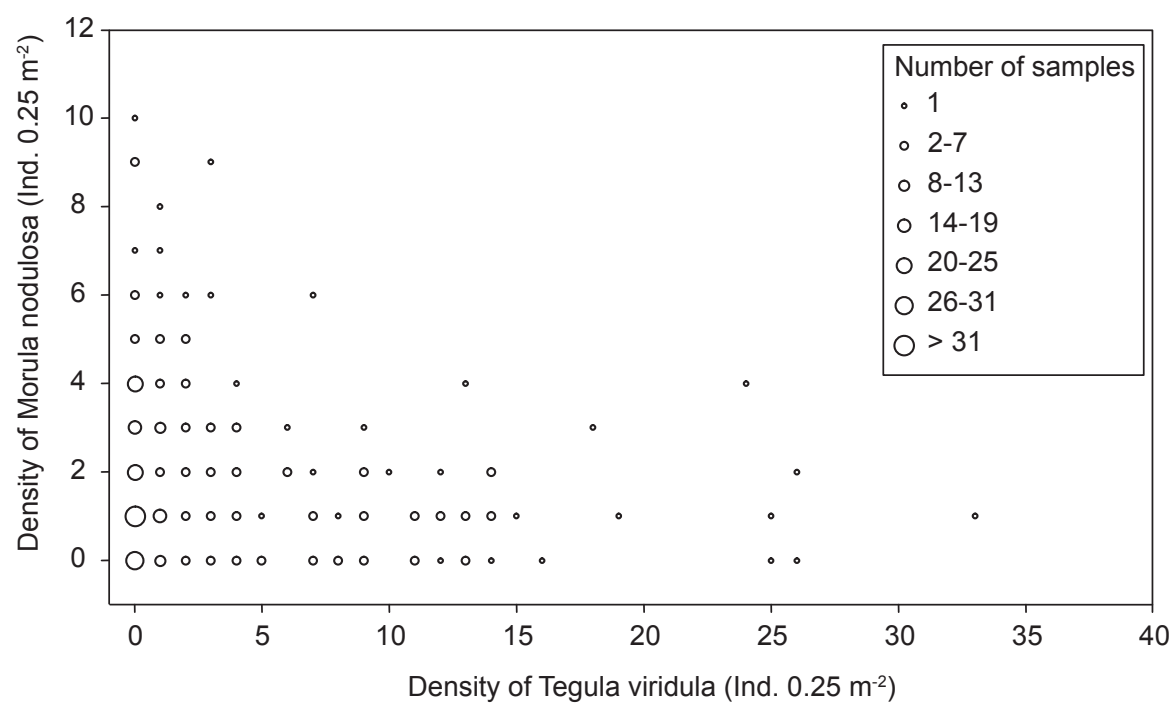

Fig. 1 - Relationship between the densities of Tegula viridula and Morula nodulosa in the samples taken from the intertidal region of the Engenho d'Água Beach, São Sebastião Channel, southeastern Brazil. 
associated with the absence or low abundance of the other.

\section{DISCUSSION}

The clumped dispersion pattern of T. viridula may be a consequence of the low availability of the preferred microhabitats of exposed rocky surfaces, while the random dispersion pattern of $M$. nodulosa may be associated with the widespread occurrence of the microhabitats it inhabits. In fact, the abundance of shelters (or preferred microhabitats) may be of fundamental importance in determining the distribution of intertidal organisms. Moran (1985) showed that aggregation in Morula marginalba is associated with the small number of shelters. Thus, the presence of pebbles and cobbles and, hence, of numerous small shelters in the study area, may favor the greater dispersion of the individuals of M. nodulosa.

A similar evaluation revealed that $T$. viridula also showed a highly significant clumped dispersion on the São Francisco beach $(I=1734.261$, $\mathrm{d}=41.259$, df = 156; A. Turra, pers. obs.), another sandy beach covered by rock fragments in the São Sebastião Channel. This suggests that aggregation in this species may be a behavioral response against desiccation, as demonstrated by Marchetti \& Geller (1987) for T. funebralis. This physical constraint would be especially important for small individuals due to their faster desiccation rate (Marchetti \& Geller, 1987). In fact, most individuals collected in the study area were small $(<0.7 \mathrm{~mm}$ in shell width, pers. obs.), corroborating previous findings (C. A. Magalhães, pers. com.) that indicate that recruitment of this species may be concentrated in such specific microhabitats, i.e., bare pebbles and cobbles not surrounded or covered by sediment. Thus, the patchiness of this kind of microhabitat may be associated with (or causing) the patchy distribution of $T$. viridula on both a micro (present study) and meso-scale (see Leite et al., 1998).

The different patterns of microhabitat use by these two species may also be caused by their distinct feeding habits. Tegula viridula is a herbivorous gastropod that feeds on encrusted microalgae (Moreira-Filho, 1960), and the presence of sediment may make it difficult for this gastropod to attach to rocks and forage over rocky surfaces. In contrast, the greater microhabitat heterogeneity resulting from the presence of sediment and brown algae may favor the occurrence of large numbers of animals such as barnacles, bivalves and other gastropods upon which $M$. nodulosa feed (Magalhães, 2000). Alternatively, predators were demonstrated to shape the distribution of T. funebralis (Paine, 1969). Because M. nodulosa is an important drilling gastropod predator in the São Sebastião Channel (Magalhães, 2000), it is possible that habitat-related predation of $M$. nodulosa on juvenile $T$. viridula could be in part responsible for this microhabitat separation.

Despite the aforementioned hypotheses to explain the dissimilar use of microhabitats by these two gastropods, an experimental evaluation of these theories should be conducted to clarify the findings of this descriptive study.

Inundation by sand in rocky environments may have a positive influence on medium-scale species diversity by maintaining habitat heterogeneity (McQuaid \& Dauer, 1990). However, sand inundation may have drastic effects on the fauna of such habitats, mainly on the psamophobic organisms (sand intolerant, sensu Brown et al., 1991). Since T. viridula grazes on exposed surfaces and does not prey upon other organisms (unlike M. nodulosa), this species is presumably less tolerant than $M$. nodulosa to sand inundation, a common feature of this dynamic environment (Denadai et al., 2000).

Acknowledgments - We would like to thank the Brazilian agencies FAPESP (Proc. No. 97/00474-8) and CNPq (Proc. $\left.\mathrm{N}^{\circ} .133468 / 95-0\right)$ for scholarships and FAEP (Proc. $\mathrm{N}^{\circ} .0222 / 95$ ) for grants for this research. The University of São Paulo Center for Marine Biology (CEBIMar-USP) provided technical assistance and logistic support. Thanks are due to Fosca P. P. Leite, Cláudia A. Magalhães and André V. L. Freitas for their helpful comments on the manuscript.

\section{REFERENCES}

AMARAL, A. C. Z., DENADAI, M. R., TURRA, A. \& RIZZO, A. E., 2003, Intertidal macrofauna in brazilian subtropical sandy beach landscapes, pp. 446-455. In: A. H. F. Klein et al. (eds), PROCEEDING OF THE BRAZILIAN SYMPOSIUM ON SANDY BEACHES: MORPHODYNAMICS, ECOLOGY, USES, HAZARDS AND MANAGEMENT. Journal of Coastal Research - Special Issue 35.

BROWN, A. C., WYNBERG, R. P. \& HARRIS, S. A., 1991, Ecology of shores of mixed rock and sand in False Bay. Trans Roy. Soc. S. Afr., 47: 563-573. 
DENADAI, M. R. \& AMARAL, A. C. Z., 1999, A comparative study of intertidal molluscan communities in sandy beaches, São Sebastião Channel, São Paulo State, Brazil. Bull. Mar. Sci., 65: 91-103.

DENADAI, M. R., AMARAL, A. C. Z. \& TURRA, A., 2000, Annual variation of the malacofauna on two intertidal sandy substrates with rock fragments in southestern Brazil. Revta Bras. Ocean., 48: 141-150.

ELLIOTT, J. M., 1977, Some methods for the statistical analysis of samples of benthic invertebrates. Freshwater Biological Association Scientific Publication, Cebu City, Philippynes, Issue $25.157 \mathrm{p}$

LEITE, F. P. P., TURRA, A. \& GANDOLFI, S. M., 1998, Hermit crabs, gastropod shells and environmental structure: Their relation in southestern Brazil. Jour. Nat. Hist., 32: 1599-1608.

MAGAlHÃES, C. A., 2000, Partilha de recursos em guilda de gastrópodes predadores em costões rochosos de São Sebastião, SP. PhD thesis - Universidade Estadual de Campinas, Brazil. 125p.
MARCHETTI, K. E. \& GELLER, J. B., 1987, The effects of aggregation and microhabitat on desiccation and body temperature of the black turban snail, Tegula funebralis (A. Adams, 1855). The Veliger, 30: 127-133.

MCQUAID, C. D. \& DOWER, K. M., 1990, Enhancement of habitat heterogeneity and species richness on rocky shore inundated by sand. Oecologia, 84: 142-144.

MigotTo, A. E., TIAGO, C. G. \& MAGAlHÃES, A. R. M., 1993, Malacofauna marinha da região do Canal de São Sebastião, SP, Brasil: Gastropoda, Bivalvia, Polyplacophora e Scaphopoda. Bolm Inst. Oceanogr., São Paulo, 41: 13-27.

MORAN, M. J., 1985, The timing and significance of sheltering and foraging behaviour of the predatory intertidal gastropod Morula marginalba Blainville (Muricidae). Jour. Exp. Mar. Biol. Ecol., 93: 103-114.

MOREIRA FILHO, H., 1960, Diatomáceas no trato digestivo de Tegula viridula Gmelin. Bolm. Univ. Par, Botânica, 1: 1-23.

PAINE, R. T., 1969, The Pisaster-Tegula interaction: prey patches, predator food preference, and intertidal community structure. Ecology, 50: 950-961. 